日臨外会誌 $66(9), 2236-2241,2005$

症例

後天性 von Willebrand 病に発症した S 状結腸癌の 1 例

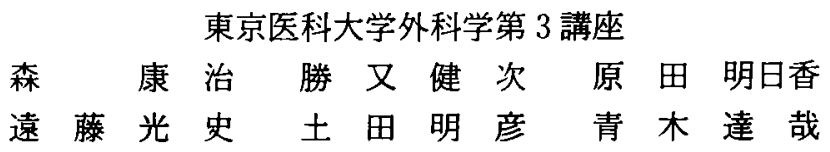

術前検査にて後天性 von Willebrand（vW）病と診断され，術中術後の $\mathrm{vW}$ 因子含有 第忡因子濃縮製剤（Ⓒonfact F) 投与により良好な止血管理が得られた S 状結腸癌の 1 例を経験した。症例は78歳, 男性. 67歳時に前立腺切除術を行った際に異常出血を認 め，精査にて $\mathrm{vW}$ 病を指摘されていた。平成16年 7 月下血を主訴に近医受診し，S 状結 腸癌を指摘された。術前の血液凝固因子輸注試験において vW 因子活性の半隇期が短い ことより，後天性の、W 病と診断した。術中術後にリストセチンコファクター（RCo） 活性を $40 \%$ \%以上に保つため，第12病日まで Confact $\mathrm{F}$ 製剤の持続投与を行い，第VII因子 凝固活性およびRCo 活性を良好に保ち止血管理が可能であった。

後天性 $\mathrm{vW}$ 病に対する全身麻酔下大手術症例報告は，本邦では 2 例目であり若干の考 察を交えて報告する.

索引用語：大腸癌, 後天性 von Willebrand 病

\section{緒 言}

後天性 von Willebrand 病は本邦登録症例が 5 例と 非常に稀な血液疾患であり, major surgeryにおける 止血法については報告が少ない.今回，われわれは $\mathrm{vW}$ 因子含有第俩因子濃縮製剂（ⒸOnfact F) 投与によ り良好な止血管理が得られた S 状結腸癌の 1 例を経 験したので, 文献的考察を加えて報告する.

$$
\text { 症例 }
$$

症例：78歳, 男性.

主訴：血便.

現病歴：平成16年 7 月血便を認めて近医受診し, 精 査目的に当院紹介となった。 9 月大腸内視鏡検查にて, $\mathrm{S}$ 状結腸に $15 \mathrm{~mm}$ 大の 2 型腫瘤を認め, 手術加療目的 に11月24日入院となる。

既往歴：糖尿病, 高血圧, 61 歳：前立腺肥大症にて 経尿道的前立腺切除術 (TUR-P), 67歳：2 回目の TUR-Pにて止血困難となり von Willebrand 病（以下 $\mathrm{vW}$ 病）の診断を受ける.

家族歴： $\mathrm{vW}$ 病および凝固異常の疾患を伴った血緑

2005 年 4 月 8 日受付 2005 年 6 月 13 日採用

〈所属施設住所〉

₹ 160-0023 東京都新宿区西新宿 6-7-1
者はいない。

入院時現症: 身長 $170 \mathrm{~cm}$, 体重 $60 \mathrm{~kg}$, 筫血, 黄疸, チアノーゼなどは認めない，腹部は平坦，軟て腫瘤な ど触知せず。

血液データ：検査成績を表に示す（表 1 ）。vW 因子 (vWF) のマルチマー分析で高分子量および中分子量 マルチマーの欠損を認めた.

加熱濃縮 $\mathbf{v W}$ 因子含有第 VIII 因子製郕（Confact F）輸注試験：Confact Fを2,000単位静注した後の第 VIII因子抗原量 (vWF: Ag) の半隇期は80分, リスト七 チンコファクター $(\mathrm{RCo})$ の半減期は50分であり, そ れぞれの半減期が短く, 以上より後天性 $\mathrm{vW}$ 病と診断 した（図 1 ).

画像所見：腹部単純 X線にて，異常ガス像などは認 めない.

注腸検查にて，S 状結腸に約 $15 \mathrm{~mm}$ 大の辺縁は平滑 で,中心にわずかに宿凹を伴う腫㿔像を認める(図 2).

内視鏡所見：肛門緑より約 $40 \mathrm{~cm} の$ 部位に約 $15 \mathrm{~mm}$ 大の 2 型腫瘤を認める. 生検にて中分化腺癌の診断で あった（図 3 ).

腹部 CT, 超音波：肝内および腫瘤近傍の腸間膜内 のリンパ節に転移を認める所見は得られなかった。

平成16年11月29日 S 状結腸癌の診断にて S 状結腸 
表 1 入院時検查所見

\begin{tabular}{lrrll}
\hline WBC & $3.7 \times 10^{3}$ & $/ \mu 1$ & PT (対照) & $11.8 \mathrm{sec}(12.7 \mathrm{sec})$ \\
RBC & $3.19 \times 10^{8}$ & $/ \mu 1$ & APTT (対照) & $47.7 \mathrm{sec}(29.5 \mathrm{sec})$ \\
$\mathrm{Hb}$ & 10.7 & $\mathrm{~g} / \mathrm{dl}$ & & \\
$\mathrm{Ht}$ & 31.3 & $\%$ & vWF : Ag & $5 \%(50 \sim 150 \%)$ \\
PLT & $158 \times 10^{3}$ & $/ \mu 1$ & vWF : RCo 活性 & $18 \%(60 \sim 170 \%)$ \\
TP & 5.8 & $\mathrm{~g} / \mathrm{dl}$ & 出血時間 & $7.5 \mathrm{~min}$ \\
GOT & 17 & $\mathrm{U} / 1$ & & \\
GPT & 15 & $\mathrm{U} / 1$ & & \\
LDH & 248 & $\mathrm{U} / 1$ & & \\
ALP & 122 & $\mathrm{U} / 1$ & & \\
$\gamma$-GTP & 28 & $\mathrm{U} / 1$ & & \\
Ch-E & 0.60 & $\Delta \mathrm{pH}$ & & \\
T-Bil & $0.50 \mathrm{mg} / \mathrm{dl}$ & & \\
D-Bil & $0.15 \mathrm{mg} / \mathrm{dl}$ & & \\
CEA & $3.5 \mathrm{ng} / \mathrm{ml}$ (cut off 2.5) & \\
CA19-9 & $16.9 \mathrm{U} / \mathrm{ml}$ & \\
\hline
\end{tabular}

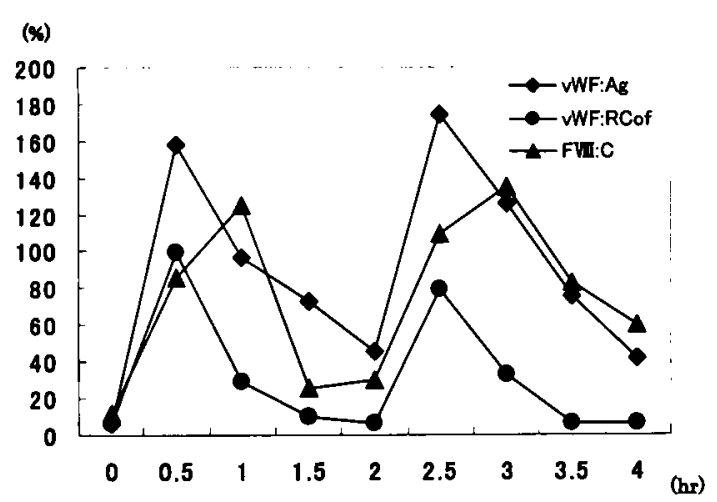

図 1 輸注試験

切除術を行った。手術時間は 2 時間28分で術中出血量 は $80 \mathrm{ml}$ であった. 術中の余分な出血を抑える目的で, 出来るだけ電気メスによる止血を避けて結紮による止 血を行った。

病理組織所見 $: 1.7 \times 1.5 \mathrm{~cm}$, moderately differentiated adenocarcinoma, ss, ly3, v2, n2 (5/8) Stage IIlb (图 4 ).

術後経過：術当日より Confact $\mathrm{F}$ 持続投与を開始 し, RCo 活性 $40 \%$ 以上を目標に維持した. 術後ドレー ン抜去までの性状と出血量のグラフを記した（図５）。 術後 3 病日目よりドレーンの性状が血性に変化をきた し始めたがドレーン排液量に変化なく, 性状も自然緩 解し腹腔内ドレーンを第 8 病日抜去した. 第 6 病日に は RBC 2.51 , Hb 8.0 と䝯血を認めたため, MAP 2 単 位の輸血を行った。第20病日目軽快退院となった。

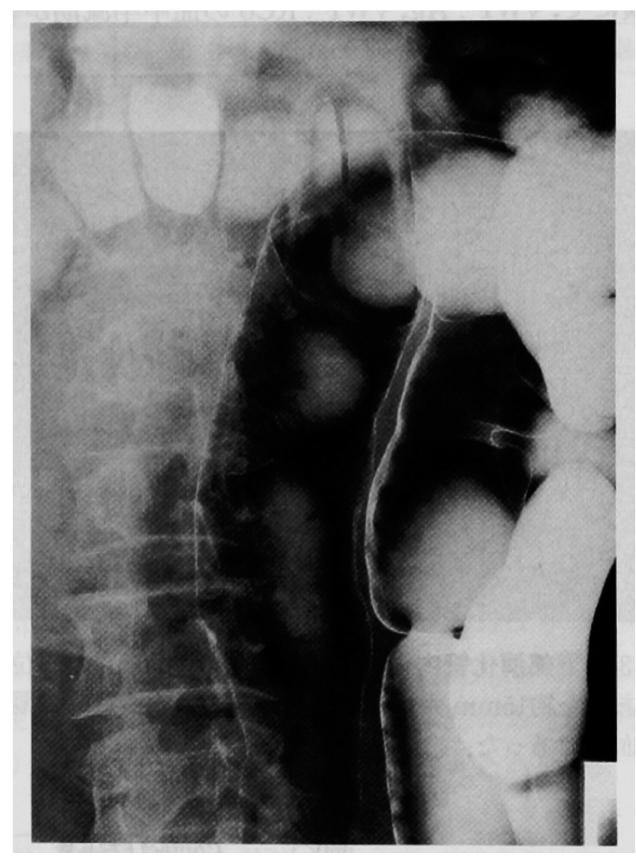

図 2 大晹注腸検査：S 状結腸に約 $15 \mathrm{~mm}$ 大の 辺緑は平滑で中心にわずかに陥凹を伴う腫瘤 像を認める。

\section{考 察}

$\mathrm{vW}$ 病は, 1926年に von Willebrandにより初めて記 載された $\mathrm{vW}$ 因子 (vWF) の量的隇少または質的異常 をきたす常染色体遺伝性出血性疾患であり，本邦の全 国調査によると 10 万人に 1 人程度の有病率と推定され ている. 臨床症状としては, 幼少時から出血症状を呈 
するが，軽症例では年長になってから外傷，手術，分 婏などの外的要因が加わったときに発見されることも 多い。また加齢とともに出血傾向が軽減する傾向にあ $3^{1)}$. $\mathrm{vW}$ 病の病因, 病態はきわめて多様で, 現在では マルチマー構造と連伝形式などに基づきI型（典型 例), II型 (変異型)，III型（重症型）に分類される. 病型別頻度では I 型約70\%, II 型 9 15\%, III型 6〜21 \%とされている，I型およびI型には多種の亜型が存 在する ${ }^{2)}$. 更にこれら以外にも血小板型, 後天性の vW 病が存在する。本症例では, 幼少時よりの出血傾向を 認めないこと，67歳時の前立腺肥大手術時の血液凝固 系検査によって止血異常を初めて指摘され $\mathrm{vW}$ 病の 診断を受けており，出血傾向を持った血縁者はいない. また入院時の vWF : Ag $5 \%$, vWF : RCo 18\%と著減 しており，加熱濃縮第VII因子製風 (Confact F) の輸注 試験にて, vWF : Ag, vWF : RCo の血中半減期が著明

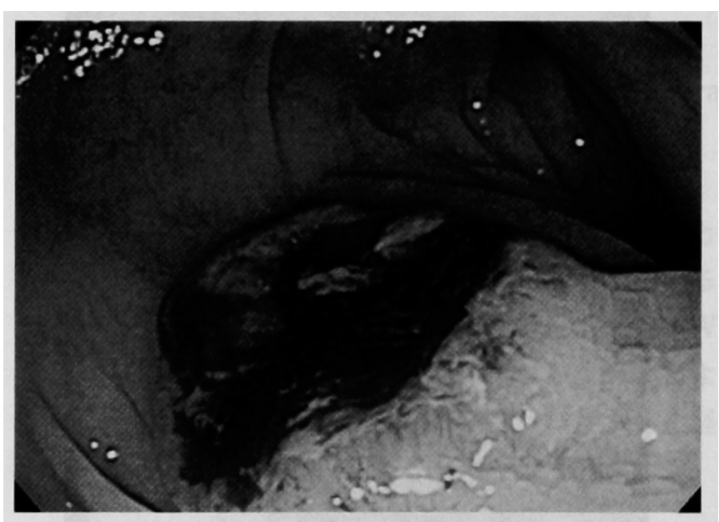

図 3 下部消化管内視鏡：肛門縁より約 $40 \mathrm{~cm}$ の部位に あった約 $15 \mathrm{~mm}$ 大の 2 型腫瘤を認める。潰瘍底は易出 血性であった。
に短縮していることより後天性 von Willebrand 症候 群と診断した。

後天性 von Willebrand 症候群とは，一般的に自己 免疫性疾患(SLE), 良性モノクローナルガンマグロフ リン血症, リンパ増殖性疾患（多発性骨髄腫, 悪性り ンパ腫など), 慢性骨髄増殖性疾患 (本態性血小板血症 など), 甲状腺機能低下症, angiodysplasia, telangiectasia などの各種疾患に合併して vWF の量的ま たは質的異常がみられることがあり，一括して後天性 von Willebrand 症候群という。世界的に280例前後の 報告があり，2005年度の日本の登録患者数は 5 名のみ で非常に稀な疾患とされる34). 基礎疾患としてはリン パ増殖性疾患 $(37 \%)$ ，骨髄増殖性疾患 $(18 \%)$ ，悪性 新生物 $(5 \%)$ ，自己免疫疾患 (5\%) などとされ る(1)610). また固形癌では, Wilms 腫癔で10\%前後の頻 度で合併するとされている7 9). 発生機序は不明な点 が多いが，(1)血中に vWF に対する抗体がありその活

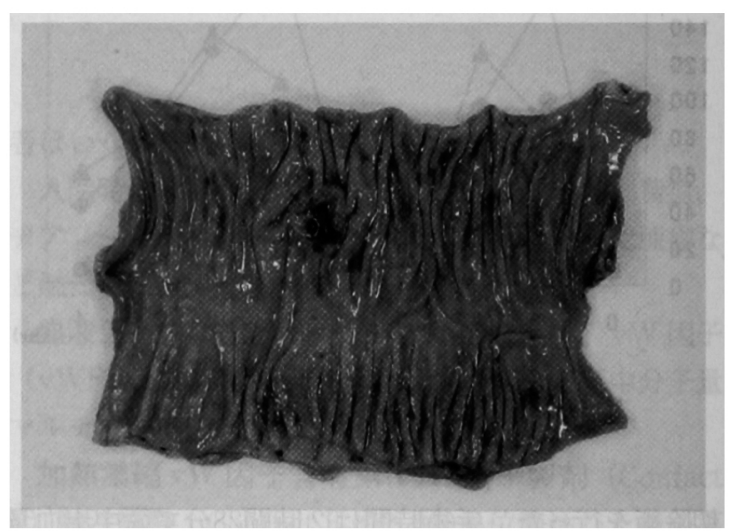

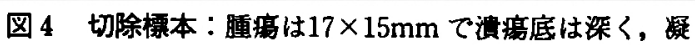
血塊を伴っていた。

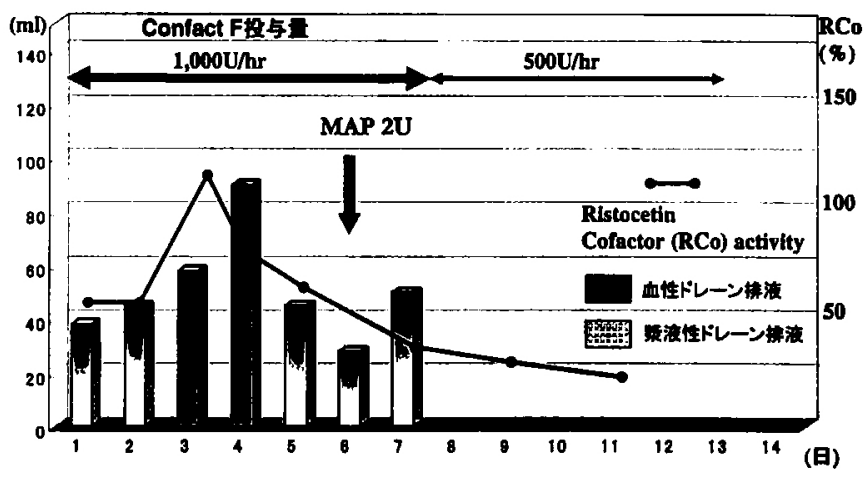

図 5 術後ドレーン排液量，RCo 活性の推移と Confact F 投与至 
表 $2 v W$ 病患者の major surgery 本邦報告例

\begin{tabular}{|c|c|c|c|c|c|c|c|c|c|}
\hline 報告者 & $\begin{array}{l}\text { 報告 } \\
\text { 年度 }\end{array}$ & 年龆 & 性別 & Type & 病名 & 手術 & 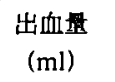 & 止血法 & 術後経過 \\
\hline 相原ら & 1987 & 42 & 女性 & I & 胆石症 & 胆菒摘出術 & 140 & Confact $\mathrm{F}$ & 7 日後拢录 \\
\hline 清水ら & 1990 & 39 & 女性 & II A & 卵鉴平滑筋隀 & 子宮全摘 & 2,800 & Confact F（持続） & 24日後退院 \\
\hline 清水ら & 1992 & 19 & 女性 & I & 心房中隔欠損症 & 開心術 & 記载なし & Confact $\mathrm{F}$ & 17日後退院 \\
\hline 工㚼ら & 1998 & 12 & 男性 & II A & 虫垂资 & 虫垂切除術 & 記載なし & Confact $\mathrm{F}$ & 軽快退院 \\
\hline Tatebe 5 & 1997 & 5 & 女性 & 血小板型 & 心房中隔欠損症 & 開心術 & 65 & - & 19日後退院 \\
\hline 鈴木ら & 2000 & 15 & 女性 & - & 卵果烡腫 & 卵巣切除術 & 1,300 & Confact $\mathrm{F}$ & 軽快退院 \\
\hline 小捻。 & 2000 & 67 & 男性 & I & 肺癌 & 肺部分切除 & 613 & DDAVP+Confact $\mathrm{F}$ & 18日後退院 \\
\hline 滝口ら & 2000 & 0.4 & 女性 & - & 肺静脈䞬流異常症 & 開心術 & 記載なし & Confact $\mathrm{F}$ & 軽快退院 \\
\hline 高橋ら & 2002 & 34 & 男性 & II A & 自然血気胸 & ブラ切除術 & $200 / \mathrm{hr}$ & - & 7 日後転科 \\
\hline 角田ら & 2003 & 76 & 男性 & I, III & 特発性大陽破裂 & 人工肛門造設 & 記载なし & Confact $F$ & 軽快退院 \\
\hline 門平ら & 2004 & 39 & 女性 & 後天性 & 子宮内膜症 & 卵单切除術 & 1,000 & Confact $\mathrm{F}$ & 7 日後退院 \\
\hline 宮木ら & 2004 & 55 & 女性 & II A & 胆石症 & 胆表摘出術 & 少量 & Confact $\mathrm{F}$ & 10日後退院 \\
\hline 自倹例 & 2005 & 70 & 男性 & 後天性 & $\mathrm{S}$ 状結腸癌 & 結腸切除原 & 80 & Confact F（持続） & 20日後退院 \\
\hline
\end{tabular}

性を中和する場合, (2)免疫複合体を形成し流血中から のvWFクリアランスを早める場合, (3)異常細胞が表 面に vWF を吸着しその血中濃度を低下させてしまう 場合, (4) vWF の産生または放出そのものが傷害され る場合などが考えられる。本症例では, 輸注試験の結 果 Rco 活性の半隇期は50分，また第VIII因子疑固活性の 半隇期は 80 分, 高分子量, 中分子量はマルチマー欠損 を認めていた。悪性疾患ては, 腫場細胞が vWF の高分 子量, 中分子量のマルチマーを選択的に吸着すること があり, 従って本症例は(3)が原因による後天性 von Willebrand 症候群であると考えられたが, 術後の vWF は正常化しなかったことや, 67歳時に BPH に対 しTUR-Pを行った際に vWDが指摘されていた点よ りはっきりとした機序は不明であった。

$\mathrm{vW}$ 病の術中・術後管理について Nilsson ${ }^{11}$ は major surgeryにおける止血管理について第V四因子活 性 (VIII：C) を40〜 70\%，出血時間を 5 分以下に維持す べきとしている．またHagedorn ら゙'は，VIII：Cを50 \%以上にしておくべきであるとしており，最近でも出 血時間を正常化し, vWF : RCo を50\%以上とすること が望ましいとされる ${ }^{22}$. 本症例では術前VIII因子製剤投 与量を $1,000 \mathrm{U} / \mathrm{Hr}$ とし, $\mathrm{RCoF}$ 活性を指標として $40 \%$ 以上を目標に術後止血管理を行った。

加熱濃縮第讪因子製㓮 (Confact F) の補充療法の留 意点としては，(1) vWF の中で特に活性の高い高分子
量マルチマーを十分補充できるか否か, (2)高 fibrinogen 血症の出現, (3) inhibitor（第VIII因子免疫抗 体)の発生，(4)アレルギー性反応が問題とされる ${ }^{13144}$.

$\mathrm{vW}$ 病合併に対する本邦における全身麻酔下大手術 に対する報告例は，われわれが検索しえた範囲では自 験例を含め13例であり（表 2)，11例に第Vll|因子製㓣の 投与が行われ，いずれも良好な止血管理が行われてい る. 悪性腫瘍に対する手術症例は 1 例であり，また後 天性 $\mathrm{vW}$ 病に対する手術症例は自験例を加え 2 例 Confact Fの持続大量投与, ガンマグロブリン大量療 法により止血管理が行われていた。後天性 $\mathrm{vW}$ 病は先 天性に比べ, $\mathrm{RCoF}$ 活性の半減期が短いことが特徴で あり止血管理がより困難であると考えられた。

\section{文献}

1）高橋芳右：von Willebrand 病. 三輪史朗他編血液 病学, 第 2 版, 文光堂, 東京, $1995, \mathrm{p} 1250-1259$

2) Ruggeri ZM. Zimmerman TS : von Willebrand factor and von Willebrand disease. Blood 70 : 895-904, 1987

3) Federici AB, Rand JH, Bucciarelli $P$, et al : Acquired von Willebrand Syndrome: Data from am international Registr. Thromb Haemost $84: 345-349,2000$

4）財団法人エイス予防財団：血液疑固異常全国調查 平成15年度報告書. 東京, 2004 
5）高橋芳右：von Willebrand病の病態と DDAVP の止血効果. 協和企画通信，東京， 1985

6) Federici AB, Mannucci PM, Lombardi R, et al : Type II $\mathrm{H}$ von Willebrand disease; New structural abnormality of plasma nad platelet von Willebrand factor in a patient with prolonged bleeding time and border line levels of ristocetin cofactor activity. Am J Hematol 32 : $287-293,1989$

7) 毛利 博：後天性フォン・ウィルブランド症候群. 日血栓止血会誌 $14: 82-90,2003$

8) Coppes MJ, Zandvoort SW. Sparling CR, et al : Acquired von Willebrand disease in Wilms' tumor patients. J Clin Oncol 10:422-427, 1992

9) Scott JP, Montgomery RR, Tubergen DG, et al : Acquired von Willebrand's Disease in Association With Wilm's Tumor: Regression Fol. lowing Treatment. Blood 58:665-669, 1981

10) Facon $T$, Caron $C$, Courtin $P$, et al: Acquired type II von Willebrand's disease associated with adrenal cortical carcinoma. $\mathrm{Br} J$ Haematology 80 : 488-494, 1992

11) Nilsson IM: Hqemorrhage and Thrombotic Disease. 90, Wiley, New York, 1971

12) Hagedorn AB, Gilchrist GS, Bowie EJ, et al: The Clincal and surgical management of patients with von Willebrand's disease. Proc XIth Cong WFH, 1976, p217

13）高橋芳右：von Willebrand 病. 血液フロンティア $11: 1119-1128,2001$

14）小西理雄：血友病 A 患者に伴う動脈管開存症兼 肺高血圧の手術経験. 胸部外科 $35: 774-778$, 1982

15）相原守男, 諏訪義光, 山内 誠他：加熱製剤第VII 因子製郕 (Confact-F) を輸注し胆言摘出術を施行 した von Willebrand 病の 1 例. 臨と研 $64: 645$ $-649,1987$

16）清水康史, 大塚伊佐夫，小山崇夫他：von Wille- brand 病を合併した 1 症例の術中, 術後管理にお ける加熱溄縮VIII因子製剤の止血効果. 日産婦会誌 $42: 1591-1594,1990$

17）清水浩一, 荒川裕国, 丸山俊之他: von Willebrand 病を合併した心房中隔欠損症の 1 治験例.

日胸外会誌 $40: 1261-1266,1992$

18）江畑貴文, 唐沢富士夫, 佐藤哲雄 : 喘息の既往か ある von Willebrand 病患者の麻酔経験. 麻酔 $47: 992-994,1998$

19) Tatebe $S$, Kanazawa $H$, Yamazaki $Y$, et al : Closure of a Ventricular Septal Defect in a patient with von Willebrand Disease. Surg Today $27: 661-663,1997$

20）鈴木宗三, 石川正明, 阿久津保之他：父親は内痔 核手術後, 娘は笈巣膿腫手術後に大量の出血が見 られた von Willebrand 病の 1 家系. 東北止血血 栓研会誌 $14: 1-4,2000$

21）滝口 信, 長瀬裕三, 香西 裏他: von Willebrand 病を合併した, 総肺静脈罢流異常症の 1 手 術例. Jpn J THORACIC CARDIOVASC SURG $48: 88,2000$

22）小杉千弘, 永井完治, 河崎英典他：von Willebrand 病を合併した肺葟の 1 手術症例. 胸部外科 $53: 464-467,2000$

23）高橋康宏, 齊藤克憲, 岩代 望他: von Willebrand 病に合併した自然血気胸の 1 例. 日臨外会 誌 $63: 345-347,2002$

24）角田裕子, 柳沼良夫, 佐々木由美子他：特発性大 腸穿孔を来し，止血管理にガンマグロブリン大量 療法が有効であった type 1，3 類似の Acquired von Willebrand syndrome. 福島医誌 $53: 87$, 2003

25）門平靖子, 山崎雅英, 前川実生他：後天性 vWD 症 例の子宮・附属器全摘術における止血管理. 日血 栓止血会誌 $15: 480,2004$

26）宮木祐一郎, 伊関丈治, 遠山和成他：Von Willebrand 病を合併した胆石症に対し胆鸾摘出術を行 つた 1 例. 静岡総合病医誌 $18: 71-73,2004$ 


\title{
A CASE OF SIGMOID COLON CANCER OCCURRED IN A PATIENT WITH ACQUIRED VON WILLEBRAND DISEASE
}

\author{
Yasuharu MORI, Kenji KATSUMATA, Asuka HARADA, \\ Mitsufumi ENDO, Akihiko TSUCHIDA and Tatsuya AOKI \\ Department of Surgery III, Tokyo Medical University
}

This paper deals with a patient with sigmoid colon cancer who was diagnosed as having acquired von Willebrand $(\mathrm{vW})$ disease preoperatively and whose hemostatic management was successfully attained by intra-and postoperative administration of a factor VIII consentrate including the factor vW (Confact $\left.\mathrm{F}^{\oplus}\right)$.

The patient was a 78-year-old man who had been suggested to have $\mathrm{vW}$ disease following examinations for abnormal bleeding at prostatectomy performed at the age of 67. In July 2003, the patient, complaining of anal bleeding, was found having sigmoid colon cancer at another hospital and was referred to the hospital. Preoperative infusion test of coagulation factor suggested a short half life period of $\mathrm{vW}$ factor activity, and thus acquired $\mathrm{vW}$ disease was diagnosed. In order to maintain the ristocetin cofactor (RCo) activity at more than $40 \%$ during and after the operation, sustained administration of Confact $\mathrm{F}$ was carried out until the $12^{\text {th }}$ hospital day. The factor VIII coagulation activity as well as RCo activity was favorably maintained, resulting in good hemostatic management.

This is the second case report on surgical management of acquired $\mathrm{vW}$ disease under general anesthesia in Japan. Some bibliographical comments are also presented here. 